\title{
Developing ESP Blended Learning for Academic Purposes of Course Materials for Students of English Education Study Program at Languages and Arts Faculty, Universitas Negeri Medan
}

DOI: https://doi.org/10.47175/rielsj.v1i3.140

\author{
| Nora Ronita Dewi ${ }^{\mathbf{1},}$ |
1,2,3 English Education Study
Program, Universitas Negeri \\ Medan, Indonesia \\ "noradewi@unimed.ac.id
}

\section{Masitowarni Siregar ${ }^{2}$ | Anggraini Thesisia Saragih ${ }^{3} \mid$}

\section{INTRODUCTION}

Changes in the world are now entering the era of industrial revolution 4.0 or the fourth world industrial revolution where information technology has become the basis of human life. Everything becomes borderless with the use of unlimited computing power and data, because it is influenced by the development of the internet and massive digital technology as the backbone of human and machine movement and connectivity. This era will also disrupt various human activities, including the fields of science and technology (science and technology) as well as higher education. 
Several campuses have taken a policy of deactivating lecture activities in the campus environment to carry out sterilization and self-quarantine students, lecturers and education personnel, including not conducting meetings in public places as well as turning on lectures and online thesis / thesis guidance. However, with the conventional lecture tradition, the choice of learning online from their respective residences is not easy. First, it requires device readiness and of course the internet data package is still managed independently. Second, not all lecturers and students are ready to operate the online learning system quickly, including preparing digital lecture materials. The industrial revolution 4.0 allows us to carry out renewable initiatives to maximize the functions of communication, information transfer and knowledge. The world may be plague and squeezed by slowing growth, but the world of education must keep running in order to continue civilization.

Educators / Teachers must ensure teaching and learning activities continue even though students are at home, learning innovations are solutions that need to be designed and implemented by teachers by maximizing existing media such as online media. Teachers can carry out learning using the E-Learning method, namely learning to utilize information and communication technology. The learning system is carried out through a computer (PC) or laptop connected to an internet network connection, teachers can learn together at the same time using groups on social media such as Whatsapp (WA), telegram, Zoom application or other social media as a learning tool so that they can make sure students learn at the same time even in different places. The teacher can also give measurable tasks but still ensure that each day of student learning is carried out step by step from the task. There are many other innovations that educators can do to ensure learning continues and students get knowledge according to the curriculum that has been prepared by the government.

Online technology is a technological development that really helps us in communicating, especially for two-way communication over long distances. This online technology is a communication that is exchanged and connected, can be used simultaneously which involves many people or only with 2 (two) people. However, this Online Technology also requires supporting devices such as computers, smartphones or other assistive devices that are used as intermediaries, especially having to be connected to the Internet. With Online Technology, it is hoped that all work can be done in support of work, Learning and Teaching. Where are the benefits of Online Technology to support work, namely by using an e-Commerce facility or online trading and using an e-Banking or online banking facility, while to support the Learning and Teaching program with Online Technology, namely through an e-Learning facility or online learning where students and teachers can communicate easily interact with different distances and places.

Apart from that, in welcoming the era of the industrial revolution 4.0, the readiness of human resources (HR) is an important factor that must be considered in education, especially higher education, has a very significant role in preparing skilled human resources who are ready to compete in the present.

In the 21 st century, teacher work is a complex and difficult job in line with large and rapid changes in the school environment driven by advances in science and technology, changing demographics, globalization and the environment. Teacher competence in the 21 st century, professional teachers are no longer just teachers who are able to teach well but teachers who are able to become learners and agents of school change, and are also able to establish and develop relationships to improve the quality of learning in their schools. For that, teachers need effective professional development, namely guidance. In the 21 st century, humans experience the development of science in all fields. One of the 
most prominent is the field of information and communication. This seems to make the world more time-consuming because all information from around the world can be accessed instantly and quickly by anyone, anywhere.

Teachers in the 21st century are challenged to accelerate the development of information and communication. Advances in information technology have increased flexibility in the acquisition of knowledge for each individual, both teachers and students. Consequently, teachers are required to be able to develop learning approaches and strategies that are in accordance with environmental developments.

The teacher is a professional position that provides expert services and demands academic, pedagogical, social and professional proficiency requirements. The results of the teacher competency test in 2015 showed that teacher pedagogical competence was low, placing the LPTK as the most responsible institution with low competence. It is well known that teachers are the products of the LPTKs, so that the LPTKs are the institutions that are more responsible for these conditions. Teacher is a professional position in the field of education. As a position, teachers must be prepared through education within a certain period of time with a certain set of subjects according to their level. The education in question is to educate prospective teachers who are capable of carrying out tasks in a professional manner.

The general problem that is often faced by lecturers in the ESP course is that there are still quite a lot of lecturers who have not used this KKNI-based 6 assessment rubric perfectly. Actually there are many factors that cause this problem, both factors that are within the lecturer and factors that are outside the lecturer. Therefore, the researchers conclude that the teaching of ESP seems appropriate when connected with the role of the lecturer by referring to the KKNI curriculum reference in carrying out the learning process.

\section{Research Objectives}

The objectives of this study are:

1. Knowing and understanding teaching materials and worksheets in accordance with the needs of the IQF-based ESP teaching in semester 7 in the English Education Study Program.

2. Developing appropriate KKNI-based teaching materials and worksheets used in the teaching of ESP in semester 7 in the English Education Study Program through Blended Learning.

This research was conducted by developing an assessment tool with reference to the PBM process in the KKNI curriculum which involved 6 assignments, namely Routine Tasks (TR), Critical Journal Review (CJR), Critical Book Report (CBR), Engineering Idea (Idea Engineering), Project and Mini. Research (Mini Research) in teaching ESP.

By entering the fourth industrial revolution, academics and students and all actors in the world of education at the tertiary level are taking part in the development of digital devices. According to the Minister of Research, Technology and Higher Education, there are five important elements that must be of concern to encourage economic growth and national competitiveness in the era of the Industrial Revolution 4.0, namely:

1. Preparation of a more innovative learning system in higher education, such as adjusting the learning curriculum, and improving student abilities in data Information Technology (IT), Operational Technology (OT), Internet of Things (IoT), and Big Data Analytics, integrating objects physical, digital and human to produce competitive and skilled college graduates, especially in the aspects of data literacy, technological literacy and human literacy. 
2. Reconstruction of higher education institutional policies that are adaptive and responsive to the 4.0 industrial revolution in developing the required transdisciplinary and study programs. In addition, he began to strive for the Cyber University program, such as a distance learning system, thereby reducing the intensity of lecturer and student meetings. Cyber University is expected to be a solution for the nation's children in remote areas to reach quality higher education.

3. Preparation of human resources, especially lecturers and researchers as well as engineers who are responsive, adaptive and reliable to face the industrial revolution 4.0. Apart from that, rejuvenation of infrastructure and infrastructure development for education, research and innovation is also necessary to sustain the quality of education, research and innovation.

4. Breakthrough innovation and strengthening of innovation systems to increase industrial productivity and increase technology-based startups.

Based on the background description of the problem above, the problem formulations in this study are as follows:

1. Are the teaching materials and worksheets used in the English Education Study Program in the ESP course in semester 7 in accordance with the IQF standard?

2. What are the appropriate Teaching Materials and Worksheets for teaching ESP in semester 7 in the English Language Education Study Program developed based on KKNI through Blended Learning?

This research will link the influence of the development of KKNI-based Teaching Materials and Worksheets on ESP courses. The findings will provide information, especially for English lecturers in general, and its usefulness for students in particular. These findings will provide information about the development of IQF-based learning tools that are appropriate and suitable for ESP teaching through Blended Learning, which can be used by lecturers and students so that they can better carry out investigations related to this study in the future.

\section{LITERATURE REVIEW}

\section{Indonesian National Qualifications Framework (KKNI)}

The Indonesian National Qualifications Framework (KKNI) is a qualification ranking framework for Indonesian human resources that juxtaposes, equals, and integrates the education sector with the training and work experience sectors in a work ability recognition scheme that is tailored to the structures in various work sectors.

$\mathrm{KKNI}$ is the embodiment of the quality and identity of the Indonesian nation related to the national education system, the national job training system, and the national learning outcomes assessment system, which is owned by Indonesia to produce quality and productive national human resources.

The KKNI states that there are nine qualification levels for productive Indonesian human resources. The description of qualifications at each level of the IQF comprehensively considers a complete learning outcome, which can be produced by an educational process, both formal, non-formal, informal, and independent experience to be able to do quality work. The description of each qualification level is also adjusted to the development of science, technology or art, as well as the development of sectors supporting the economy and people's welfare, such as industry, agriculture, health, law and other related aspects. Learning outcomes also include aspects of building national identity as reflected in Pancasila, the 1945 Constitution, and Bhinneka Tunggal Ika, namely upholding the practice of the five principles of Pancasila and law enforcement, and having 
a commitment to respect the diversity of religions, ethnicities, cultures, languages. , and art that grows and develops in Indonesian soil.

\section{(Six) KKNI-Based Assignments}

Students who study in the 2016/2017 academic year will surely be surprised by the new curriculum for lectures, especially state universities throughout Indonesia which are now implementing the KKNI curriculum (Indonesian National Qualification Curriculum), hereinafter abbreviated as KKNI, is a competency qualification ranking framework that can match, equalize, and integrating education and job training as well as work experience in order to recognize work competencies in accordance with job structures in various sectors.

Especially universities whose educational focus is teacher training or LPTK (Educational Personnel Education Institutions) such as UNIMED, UM, UNM, UPI, UNJ, and many more have implemented this curriculum starting from the new school year that has passed, as for the content of this curriculum is mandatory Each student performs 6 Compulsory Tasks which are made so that students can truly live the meaning of the lecture itself. The 6 routine tasks include:

\section{Routine Tasks}

Routine assignments in lectures that use KKNI as the curriculum require all students to accept and do routine assignments given by the lecturer. Routine assignments are a form of assignments given by lecturers in lectures in the form of free test questions, quizzes, opening questions or in other forms given to students at the beginning of the lecture, it could be in the middle or the end or even in each lecture material that the lecturer is giving to students.

\section{CBR (Critical Book Report)}

From the name, CBR (Critical Book Report) is a task in which we are required to criticize 2 or more accredited pieces, namely the main book in English, in which the first book we will mention the main book and the second comparison book in Indonesian and Indonesian. English.

Usually the lecturer will ask for 2 books as a comparison and one main book in English is made in a summary form, but it depends on the willingness of the lecturer who is a master of the class, the important thing in this task is that we have to think as creatively as possible in criticizing the contents of a book without putting aside the things that the lecturers ask of you in the process.

\section{CJR (Critical Journal Review)}

CJR (Critical Journal Review) is a task that requires students to be able to criticize a national and international journal and review it again in order to find a new understanding that is easier for those who review and who read the journal's review to understand.

Basically, reviewing journals is not too difficult as long as we understand the stages of the process, because usually students are lazy to do this journal review because they don't understand or don't fully understand how to make CJR (Critical Journal Riview) because there is no guidance from the campus or the lecturer concerned.

\section{Idea Engineering}

Idea engineering is the task of one of the tasks in the KKNI education curriculum that requires students to create a new idea, or engineer an existing idea to be better or can be 
said to be more efficient than before. From the name Idea Engineering is a task that creates, updates, modify an idea, either an existing idea or an original excavation from one's own mind without any plagiarism element in the arrangement. Completing the Engineering Task This idea is tricky, because it is related to finding an idea, which means that in completing this task students are required to do more. critical and creative in coming up with a new idea or engineering an existing original idea for something useful, of course, and if you find an idea or design it, it is not impossible that you can apply it in the form of mini research to create a product in the form of a small project.

\section{Mini Research}

Mini Riset adalah tugas yang berbentuk penelitian dalam skala kecil yang diberikan dosen kepada mahasiswa agar dapat langsung mempraktikkan apa yang telah mereka pelajari dalam materi perkuliahan dalam bentuk penelitian dilapangan.adapun penelitian ini disusun dalam bentuk laporan yang sistematika dan formatnya akan ditentukan oleh dosen itu sendiri.Adapun tujuan dari Mini Riset ini adalah mendapatkan hasil dari sebuah penelitian yang dilaksanakan dalam lingkup yang tidak terlalu besar,bagaimana agar mahasiswa terlatih untuk langsung terjun kelapangan melaksanakan penelitian yang merupakan perwujudtan materi perkuliahan yang telah mereka terima.

\section{Projects}

The task of this KKNI is to require students to make a project on a small or large scale which is a continuation of the Mini Research that has been carried out, which means that in making this assignment students are required to create a real product which is a reflection of the small research that has been carried out in previous assignment.

The purpose of this project's task is to train students to work independently or in groups in creating a product that is beneficial to society.

\section{Teaching Instruments}

The learning device itself is a medium that is used as a guide or guide in a learning process. The learning device itself has a goal to fulfill a teacher's success in learning. Tools are a number of materials, tools, media, instructions and guidelines that will be used in the process of achieving the desired activities. And learning is a process of collaboration between teachers and students in utilizing all the potential and existing resources, both potential that comes from within themselves such as interests, talents and basic abilities possessed including learning styles and potentials that exist outside students such as the environment learning facilities and resources as an effort to achieve certain learning goals. (Sanjaya, 2010: 26). So in other words, learning devices are tools or equipment to carry out processes that allow educators and students to carry out learning activities. Learning devices become a guide for teachers in carrying out learning both in the classroom, laboratory or outside the classroom.

A syllabus is a learning plan for a particular subject and / or group of subjects or themes that include competency standards, basic competencies, subject matter or learning, learning activities, indicators, assessments, time allocation, and learning resources or materials or tools. The syllabus is the translation of competency standards and basic competencies into subject matter or learning, learning activities and competency achievement indicators for assessment. (Khaeruddin et al, 2007).

The lesson plan (RPP) is a lesson plan per unit that the teacher will set in classroom learning. RPP is basically a plan to estimate or project what will be done in learning. Thus, the lesson plan is an attempt to estimate the actions to be taken in learning activities. RPP 
needs to be developed to coordinate learning components, namely: basic competencies, standard materials, indicators of learning outcomes, and assessment.

\section{Teaching Materials}

Teaching materials are materials or subject matter that are systematically arranged, which teachers and students use in the learning process (Pannen, 1995). Teaching materials are a set of learning tools or tools that contain learning materials, methods, limitations, and ways of evaluating which are designed systematically and attractively in order to achieve the expected goals, namely achieving competence or sub-competence with all its complexities (Widodo and Jasmadi in Lestari, 2013: 1). This understanding explains that a teaching material must be designed and written in instructional principles because it will be used by the teacher to help and support the learning process. Materials or learning materials are basically the "content" of the curriculum, namely in the form of subjects or fields of study with topics / subtopics and details (Ruhimat, 2011: 152).

\section{Learning Media}

Learning media in general is a tool for teaching and learning. Everything that can be used to stimulate thoughts, feelings, attention and abilities or skills of learners so as to encourage the learning process. This limitation is quite broad and deep, covering the understanding of resources, environment, people and methods used for learning / training purposes. Meanwhile, according to Briggs (1977) learning media is a physical means of conveying learning content / material such as books, films, videos and so on. Then according to the National Education Association (1969) revealed that learning media is a means of communication in the form of print and view-hearing, including hardware technology.

\section{Student Worksheet (LKPD)}

Student worksheets (LKPD) are a means to assist and facilitate teaching and learning activities so that effective interactions will be formed between students and educators, so as to increase student activities in increasing learning achievement. Widjajanti (2008: 1) states that student worksheets (LKPD) are a learning resource that can be developed by educators as facilitators in learning activities. LKPD that is compiled can be designed and developed in accordance with the conditions and situations of learning activities to be faced. Meanwhile, according to the Ministry of National Education (2008) student worksheets (LKPD) are sheets containing tasks that must be done by students. Activity sheets are usually instructions, steps for completing a task. The advantage of using LKPD is that it makes it easier for educators to carry out learning, for students they will learn independently and learn to understand and carry out a written assignment.

\section{Evaluation}

Bloom (1971) defines evaluation, as we have seen, as a systematic collection of facts to determine whether in reality there has been a change in students and to determine the extent of changes in the student's personality. In line with that, Stufflebeam (1971) says that evaluation is a process of describing, obtaining, and presenting information that is useful for assessing decision alternatives.

Evaluation is a process for planning, obtaining, and providing information that is indispensable for making several alternatives in making decisions. In accordance with this definition, any evaluation or assessment activity is a process that is deliberately carried out 
to obtain information or data; based on these data then try to make a decision. Where the data information collected must be appropriate data and support the objectives of the planned evaluation.

\section{ESP}

English for Specific Purposes (ESP) is conducted to equip students with a certain level of English proficiency for situations in which the language will be used, called target needs. Because it provides teaching objectives, materials and methods developed based on the needs and potential interests of learners, since the early 1960s, ESP has developed into one of the most prominent fields of English foreign language. Currently, ESP is not only applied to adults of English learners who have mastered a basic level of English proficiency or those who have a specific goal of learning English, but it is also adopted for English learners learning general English.

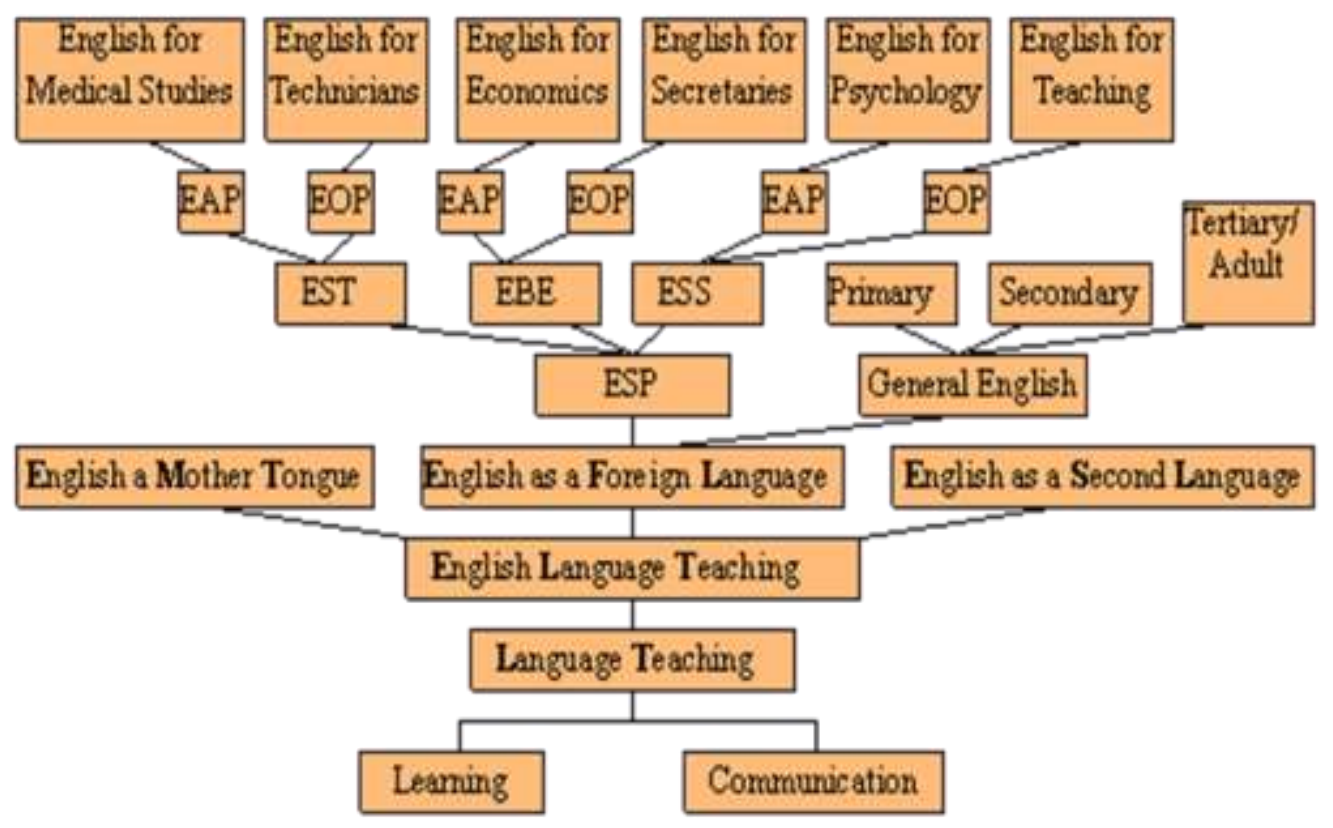

Figure 1. Tree of ESP (Hutchinson \& Waters, 1987)

E-learning is an educational system or concept that utilizes information technology in the teaching and learning process. Learning is structured with the aim of using an electronic or computer system so that it is able to support the learning process (Michael, 2013: 27). In particular, e-learning basically has 4 characteristics, including:

1. Have content that is relevant to learning objectives.

2. Using instructional methods, such as presenting examples and exercises.

3. Use interesting elements such as words and pictures to convey learning material.

4. And can build understanding and abilities related to learning objectives either individually or in groups. (Prayudi, 2007)

\section{Blended Learning}

Etymologically, the term Blended Learning consists of two words, namely Blended which means mixture and Learning which means learning. Thus, at a glance, Blended Learning means learning patterns that contain elements of mixing or combining one pattern with another in learning. Mosa in Kumar (2006) states that what is mixed in blended learning are two main elements, namely classroom lessons with online learning. 
Blended learning is a learning method that combines face-to-face meetings with online material in harmony. A combination of conventional learning where educators and students meet directly with online learning that can be accessed anytime and anywhere. Another form of blended learning is a virtual meeting between educators and students. Where between educators and students may be in two different places, but they can give each other feedback, ask questions, or answer. Everything is done in real time.

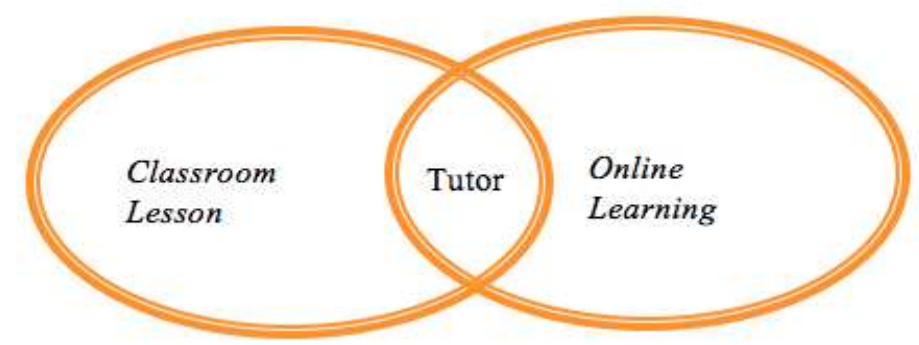

Figure 2. Blended Learning. Source: Rusman, et al (2012: 242)

\section{RESEARCH METHODS}

\section{Research Design}

The development of IQF-based learning tools for ESP teaching in the English Language Education Study Program (PS Dik. B. English) -Unimed uses a research and development design (Research and Development). This method is a research method used to produce products and test the effectiveness of these products (Sugiono, 2010).

\section{Research Locations}

This research was conducted in the test of validation test for teaching materials and worksheets based on the KKNI against ESP courses in the English-Unimed Education Study Program, Jalan Willem Iskandar Pasar V Medan.

\section{Population and Sample}

The population and sample in this study were 7th semester students in the ESP subject for Regular Education classes A and B.

\section{RESULTS AND DISCUSSION}

\section{Collecting Data and Information}

Data and information in this study were obtained from preliminary observations on the 7th Semester English Education Study Program and lecturers in the ESP course. The facts show that there is no KKNI based blended learning in learning ESP courses.

\section{Development Stage}

At this stage, the development of KKNI learning tools based on blended learning in the English for Specific Purpose course is carried out in accordance with the learning objectives.

\section{Preliminary Stage}

Results of Needs Analysis

From the results of the interview, the lecturer already knew about the absence of KKNI learning tools based on blended learning in ESP course learning. For this reason, the 
syllabus, materials, media, worksheets, and evaluation based on blended learning will be used in the English for Specific Purpose course.

\section{General Information}

From the data above, it can be concluded that students understand the KKNI learning tools based on blended learning in the English for Specific Purpose course. Most of the students responded that they preferred to master speaking skills at $45.4 \%$ and writing skills by $42.5 \%$.

Necessities Analysis

\begin{tabular}{|c|c|c|c|}
\hline $\begin{array}{c}\text { Item } \\
\text { Number }\end{array}$ & Question & Responses & $\begin{array}{c}\text { Percentages } \\
(\%)\end{array}$ \\
\hline \multirow[t]{4}{*}{1} & \multirow{4}{*}{$\begin{array}{l}\text { What English skill that you } \\
\text { really need? }\end{array}$} & Reading & 7.8 \\
\hline & & Speaking & 45.4 \\
\hline & & Writing & 42.5 \\
\hline & & Listening & 4.3 \\
\hline \multirow[t]{4}{*}{2} & \multirow[t]{4}{*}{$\begin{array}{l}\text { Course materials that given } \\
\text { is expected to make you... }\end{array}$} & $\begin{array}{l}\text { Improve your ability in } \\
\text { writing English }\end{array}$ & 41.9 \\
\hline & & Master the vocabularies & 12.9 \\
\hline & & $\begin{array}{l}\text { Increase your knowledge } \\
\text { of text types }\end{array}$ & 35.5 \\
\hline & & $\begin{array}{l}\text { To be able to use the } \\
\text { correct and appropriate } \\
\text { grammar }\end{array}$ & 9.7 \\
\hline \multirow[t]{2}{*}{3} & \multirow{2}{*}{$\begin{array}{l}\text { Is your English textbook } \\
\text { suitable with your needs? }\end{array}$} & Yes & 45.2 \\
\hline & & No & 54.8 \\
\hline \multirow[t]{3}{*}{4} & \multirow{3}{*}{$\begin{array}{l}\text { Are the English materials } \\
\text { you have studied suitable } \\
\text { with the needs of students? }\end{array}$} & Very appropriate & 16.1 \\
\hline & & Appropriate & 32.3 \\
\hline & & Inappropriate & 51.6 \\
\hline
\end{tabular}

\section{Item}

Question

Responses

Percentages

Number

(\%)

\begin{tabular}{lllll}
\hline $\mathbf{5}$ & $\begin{array}{l}\text { Do } \begin{array}{c}\text { you able } \\
\text { communicate actively }\end{array} \\
\end{array}$ & to & Reading & 7.8 \\
\cline { 3 - 4 } & & Speaking & $\mathbf{4 5 . 4}$ \\
\cline { 3 - 4 } & & Writing & $\mathbf{4 2 . 5}$ \\
\hline
\end{tabular}




\begin{tabular}{|c|c|c|c|}
\hline & & Listening & 4.3 \\
\hline \multirow[t]{4}{*}{6} & \multirow[t]{4}{*}{$\begin{array}{l}\text { Do you able to understand } \\
\text { grammar in English? }\end{array}$} & $\begin{array}{l}\text { Improve your ability in } \\
\text { writing English }\end{array}$ & 41.9 \\
\hline & & Master the vocabularies & 12.9 \\
\hline & & $\begin{array}{l}\text { Increase your } \\
\text { knowledge of text types }\end{array}$ & 35.5 \\
\hline & & $\begin{array}{l}\text { To be able to use the } \\
\text { correct and appropriate } \\
\text { grammar }\end{array}$ & 9.7 \\
\hline \multirow[t]{2}{*}{7} & \multirow{2}{*}{$\begin{array}{l}\text { Do you able to understand } \\
\text { the reading in books or } \\
\text { journals in English? }\end{array}$} & Yes & 45.2 \\
\hline & & No & 54.8 \\
\hline \multirow[t]{3}{*}{8} & \multirow{3}{*}{$\begin{array}{l}\text { Do you able to understand } \\
\text { the content of a speech or } \\
\text { speech in English? }\end{array}$} & Very appropriate & 16.1 \\
\hline & & Appropriate & 32.3 \\
\hline & & Inappropriate & 51.6 \\
\hline
\end{tabular}

\begin{tabular}{|c|c|c|c|}
\hline \multirow[t]{4}{*}{9} & \multirow{4}{*}{$\begin{array}{l}\text { What skills do you } \\
\text { mostly required? }\end{array}$} & Reading & 8.2 \\
\hline & & Speaking & 48.0 \\
\hline & & Writing & 41.8 \\
\hline & & Listening & 2.0 \\
\hline \multirow[t]{4}{*}{$\mathbf{1 0}$} & \multirow{4}{*}{$\begin{array}{l}\text { Do you able to } \\
\text { understand grammar in } \\
\text { English? }\end{array}$} & $\begin{array}{l}\text { Improve your ability } \\
\text { in writing English }\end{array}$ & 41.9 \\
\hline & & $\begin{array}{l}\text { Master the } \\
\text { vocabularies }\end{array}$ & 12.9 \\
\hline & & $\begin{array}{lrr}\text { Increase } & \text { your } \\
\text { knowledge of } & \text { text } \\
\text { types } & & \end{array}$ & 35.5 \\
\hline & & $\begin{array}{l}\text { To be able to use the } \\
\text { correct and } \\
\text { appropriate grammar }\end{array}$ & 9.7 \\
\hline \multirow[t]{2}{*}{11} & \multirow{2}{*}{$\begin{array}{l}\text { Do you able to } \\
\text { understand the reading } \\
\text { in books or journals in } \\
\text { English? }\end{array}$} & Yes & 45.2 \\
\hline & & No & 54.8 \\
\hline 12 & Do you able & Very appropriate & 16.1 \\
\hline
\end{tabular}


understand the content Appropriate

32.3

of a speech or speech

in English?

Inappropriate

51.6

\section{Lacks Analysis}

\begin{tabular}{|c|c|c|c|}
\hline $\begin{array}{l}\text { Item } \\
\text { Number }\end{array}$ & Question & Responses & $\begin{array}{l}\text { Percentages } \\
(\%)\end{array}$ \\
\hline \multirow[t]{3}{*}{1} & $\begin{array}{l}\text { Your English skills are in } \\
\text { the level .... }\end{array}$ & $\begin{array}{l}\text { Beginner } \\
\text { using English in a very } \\
\text { simple way. }\end{array}$ & 67.7 \\
\hline & & $\begin{array}{l}\text { Intermediate: using } \\
\text { English in accordance } \\
\text { with the existing situation } \\
\text { even though it is not } \\
\text { fluent. }\end{array}$ & 22.6 \\
\hline & & $\begin{array}{l}\text { Advanced (advanced): } \\
\text { able to use English } \\
\text { fluently and actual in any } \\
\text { situation. }\end{array}$ & 9.7 \\
\hline
\end{tabular}

\begin{tabular}{|c|c|c|c|}
\hline \multirow[t]{4}{*}{2} & \multirow[t]{4}{*}{$\begin{array}{lr}\text { What is your } \\
\text { difficulty } \\
\text { learning language? }\end{array}$} & $\begin{array}{l}\text { Arranging the } \\
\text { structure of the } \\
\text { sentences. }\end{array}$ & 22.6 \\
\hline & & $\begin{array}{l}\text { Selecting the } \\
\text { appropriate } \\
\text { word choice. }\end{array}$ & 19.4 \\
\hline & & $\begin{array}{lr}\text { Using } & \text { the } \\
\text { correct } & \text { and } \\
\text { appropriate } & \\
\text { grammar } & \end{array}$ & 41.9 \\
\hline & & $\begin{array}{l}\text { Expressing } \\
\text { ideas of the text }\end{array}$ & 16.1 \\
\hline
\end{tabular}

\begin{tabular}{|c|c|c|c|}
\hline $\begin{array}{c}\text { Item } \\
\text { Number }\end{array}$ & Question & Responses & $\begin{array}{c}\text { Percentages } \\
(\%)\end{array}$ \\
\hline \multirow[t]{3}{*}{1} & \multirow[t]{3}{*}{$\begin{array}{l}\text { I want to improve } \\
\text { my ability in English } \\
\text { by ... }\end{array}$} & $\begin{array}{l}\text { finding out the } \\
\text { meaning of the } \\
\text { words in dictionary }\end{array}$ & 48.4 \\
\hline & & $\begin{array}{l}\text { filling in the blank } \\
\text { with the correct } \\
\text { word }\end{array}$ & 16.1 \\
\hline & & guessing & 16.1 \\
\hline
\end{tabular}




\begin{tabular}{lll}
\hline & $\begin{array}{l}\text { meaning of the } \\
\text { word provided }\end{array}$ & \\
& matching the word & 19.4 \\
(vocabulary) with & \\
the meanings that \\
have given
\end{tabular}

\section{CONCLUSION}

Researchers develop learning tools in the English for Specific Purposes (ESP) course by making teaching materials, media, worksheets, and evaluations. The text developed is in the form of material that is in accordance with the results of the needs analysis, namely on speaking and writing skills. There are 6 stages in making these teaching materials, namely collecting data and information, designing, products, validating designs, revising products, and trying products. Where the stage in this progress report is validating the learning tools for the ESP course.

\section{Suggestion}

Several suggestions were put forward in this study, there are:

1. As an implementation program of the KKNI curriculum based on Blended Learning.

2.The KKNI ESP teaching materials are integrated into four language skills that are specifically designed based on the needs of several disciplines.

\section{REFERENCES}

Brown, H. Douglas. (2001). Teaching by Principles-An Interactive Approach to Language Pedagogy Second Edition. San Francisco: Longman.

Evens-Dudley Tony dan Maggie Jo st.John. (1998). Developments in ESP: A multidisciplinary approach. Cambridge: Cambridge University Press, p.4-5.

Harsono. (2005). Pengantar Problem-based Learning. Edisi kedua, Medika-Fakultas Kedokteran Universitas Gadjah Mada.

Hasan S. Hamid. (2014). Kerangka Kualifikasi Nasional Indonesia (KKNI) dan Pengembangan Kurikulum S2 Pendidikan IPA. https://adpgsdindonesia.files.wordpress.com.

Hoadley- Maidment. (1980) McDonough. ESP in Perspectives: A Practical Guide. (London: Collin Educational Publishing, 1984). p.38.

Jo.Mc. Donough (1984). ESP in Perspective A Practical Guide. (London: Collin ELT), p.3.

Murray Print, (1992). Curriculum development and design (second edition). Sidney: Allen \& Unwin.

Naili Vidya. (2011). media pembelajaran berbasis audio konvensional https://www.academia.edu/16807845/media_pembelajaran_berbasis_audio_konvension al (diakses pada $15 \mathrm{Mei})$

Nunan, David. (1999). Second Lnguage Teaching \& Learning. Boston: Heinle \& Heinle.

Peraturan Menteri Pendidikan dan Kebudayaan Republik Indonesia Nomor 49 Tahun 2014 tentang Standar Nasional Pendidikan Tinggi

Richards, Jack C. and Rodgers, Theodore S. (2001). Approaches and Methods in Language Teaching. Second Edition. New York: Cambridge University Press. 
Sudjana, Dr. Nana. (2009). Penilaian Hasil Proses Belajar Mengajar. PT. Remaja Rosdakarya: Bandung

Sani, Ridwan Abdullah. (2016). Penilaian Autentik. Bumi Aksara: Jakarta.

Strevens. (1988) Kristen Gatehouse. Key Issues in English for Specific Purposes (ESP)Curriculum Development oleh dalam Kristen Gatehouse dalam Kristen Gatehouse/http//www.khe-service.com/7/26/2009) p.1.

Tarigan, Henry Guntur. (1992). Dasar-Dasar Kurikulum Bahasa. Angkasa:Kurikulum Paulina Robinson (1990), English For Specific Purposes (Oxford: Pergamon Press, Ltd) p.5.

Paulina.C. Robinson. (1991), ESP Today: A Practioner's Guide. (New York: Prentice Hall). p. 2-3

Zahrotul Izza. 2013. Penggunaan Media Video Dalam Pembelajaran Bahasa Inggris

di https://www.academia.edu/37217150/PENGGUNAAN_MEDIA_VIDEO_DALAM_PE MBELAJARAN_BAHASA_INGGRIS (diakses pada 15 Mei)

https://vanzsabasaje.weebly.com/lesson-3-types-of-esp.html http://edel.staff.unja.ac.id/blog/artikel/Pengertian-Blended-Learning.html https://husadaindah.wordpress.com/2012/03/31/macam-macam-e-learning/ http://www.infodiknas.com/model-pembelajaran-berbasis-e-learning.html https://www.kajianpustaka.com/2014/06/pengertian-karaktiristik-dan-manfaatelearning.html

http://www.tugaspedia.com/2017/06/7-tips-dan-trik-cara-mengerjakan-tugas.html http://edel.staff.unja.ac.id/blog/artikel/Pengertian-Blended-Learning.html https://www.kajianpustaka.com/2014/06/pengertian-karaktiristik-dan-manfaatelearning.html http://e-dufiesta.blogspot.co.id/2008/06/pengertian-e-learning.html http://edel.staff.unja.ac.id/blog/artikel/Pengertian-Blended-Learning.html 